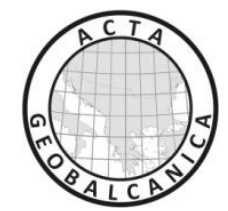

\title{
GEOCHEMICAL CHARACTERISTICS OF THE LAVA DOMES IN YATAGAN VILLAGE AND SAĞLIK TOWN, FROM ERENLERDAGI (KONYA, CENTRAL TURKEY) VOLCANITES
}

\author{
Kerim Kocak $^{1}$ \& Veysel Zedef ${ }^{1}$ \\ ${ }^{1}$ Selcuk University, Konya, Turkey. \\ Corresponding author: kkocak@yahoo.com
}

\begin{abstract}
Extensive Late Miocene to Pliocene Erenlerdagi volcanism produced lava domes, nue'e ardentes and ignimbrite deposits in west and southwest of the Konya. The domes may contain various enclaves, which range in size from a few $\mathrm{cm}$ to a few meters, and in shape cornered to spherical.
\end{abstract}

The volcanic rocks are made up of plagioclase (15-45\%), brown amphibole (3-15\%), brown biotite (5-10 $\%)$, quartz (0-5\%), sanidine (0-5\%), clinopyroxene (0-5\%), epidote (0-8\%), opaque iron ore (3-20\%), and accessory acicular apatite and zircon in a holocrystalline porphyric texture.

Geochemical data shows that all samples are high-K calc-alkaline, mostly metaluminous, and rhyodacite to andesite in composition. They are characterized by an enrichment in Large Ion lithophile Elements (e.g. Cs, K), and a depletion in High Field Strength Elements (e.g. Ti, Y). In Harker variation diagrams, $\mathrm{SiO}_{2}$ increases with increasing $\mathrm{K}_{2} \mathrm{O}, \mathrm{Na}_{2} \mathrm{O}, \mathrm{Rb}, \mathrm{Th}, \mathrm{U}, \mathrm{Nb}, \mathrm{Zr}$ contents; and decreasing $\mathrm{TiO}_{2}, \mathrm{FeOt}, \mathrm{MgO}$, $\mathrm{CaO}$ contents, suggesting fractional crystallisation of hornblende ( \pm pyroxene, olivine) and titanite. The REE pattern of the samples shows an enrichment in Light Rare Earth Elements, and a depletion in Heavy Rare Earth Elements, resultant with high [ $\left.(\mathrm{La} / \mathrm{Lu})_{N}=8.2-18.0\right]$ ratios. Existence of slight Eu anomaly (Eu/Eu*: 0.66-0.80) may suggest plagioclase fractionation in the samples.

Based on field, mineralogical and geochemical data, it has been suggested that the Erenlerdagl volcanics could have formed by chemical mixing of felsic and mafic magmas possibly coupled with fractional crystallisation of hornblende ( \pm pyroxene, olivine), plagioclase and titanite, in relation with the subduction of the African plate underneath the Anatolian plate during Miocene.

Keywords: Geology, Erenlerdă̆l, geochemistry, enclave, Konya

\section{INTRODUCTION}

Turkey is located on the Alpine-Himalayan orogenic belt and occupies a zone of convergence between two major plates, Eurasia and Afro-Arabia. The Anatolian region has been created by the amalgamation of smaller continental fragments that were formerly sited at the northern margin of Gondwana during late Palaeozoic and early Mesozoic times. Along the Miocene thrust front, collision of Eurasian and Arabian plates induced deformation of the Anatolian plate, and produced various volcanic rocks covered an area of about $85,000 \mathrm{~km}^{2}$ in East, Central and West Anatolia [1]. Acccordingly, young volcanic provinces, such as Galatia 
Volcanites (GV), Central Anatolian Volcanites (CAV) and Konya volcanites (KV), cover large areas In Central Anatolia.

The study area (Figure 1) is located approximately $50 \mathrm{~km}$ to the west of Konya (Central Anatolia). Radiometric studies suggest that the volcanic activity was initiated at $11.9 \mathrm{Ma}$ and ended 3.5 Ma [2]. In the area, a limited number of studies related to the Konya volcanics have been done [2] [3][4] [5] [6] [7] [8] [9]. However, there is no study involving geochemical characteristics of the lava domes in the study area in detail. Hence, it is aimed to determine geochemical characteristics and petrogenesis of the Miocene lava dome at Yatagan and Saglik area.

\section{GEOLOGICAL SETTING}

The study area is made up of volcanic, sedimentary and volcano-sedimentary units (Figure 1). The basement rocks of the study area are characterized by pre-Miocene ophiolitic complex, schist, quartzite and dolomitic limestone [2], which are overlain uncomformably by volcanic rocks. Based on the stratigraphic and radiometric age determination of volcanic rocks, it was suggested that Sille volcanics are the first volcanic phase [2] [10]. This unit underlied the sedimentary and volcano-sedimentary rocks, which are overlain by Kiziloren, Bulumya, Detse and Sadiklar ignimbrites, nuee ardentes and andesitic-basaltic lava and dome (Figure 1). The lava domes are located, more or less, at the center of Erenlerdagi volcanism, along with a line trending in NW-SWW direction. Upper Pliocene limestone and Quaternary fluvial and alluvium materials cover all the units.

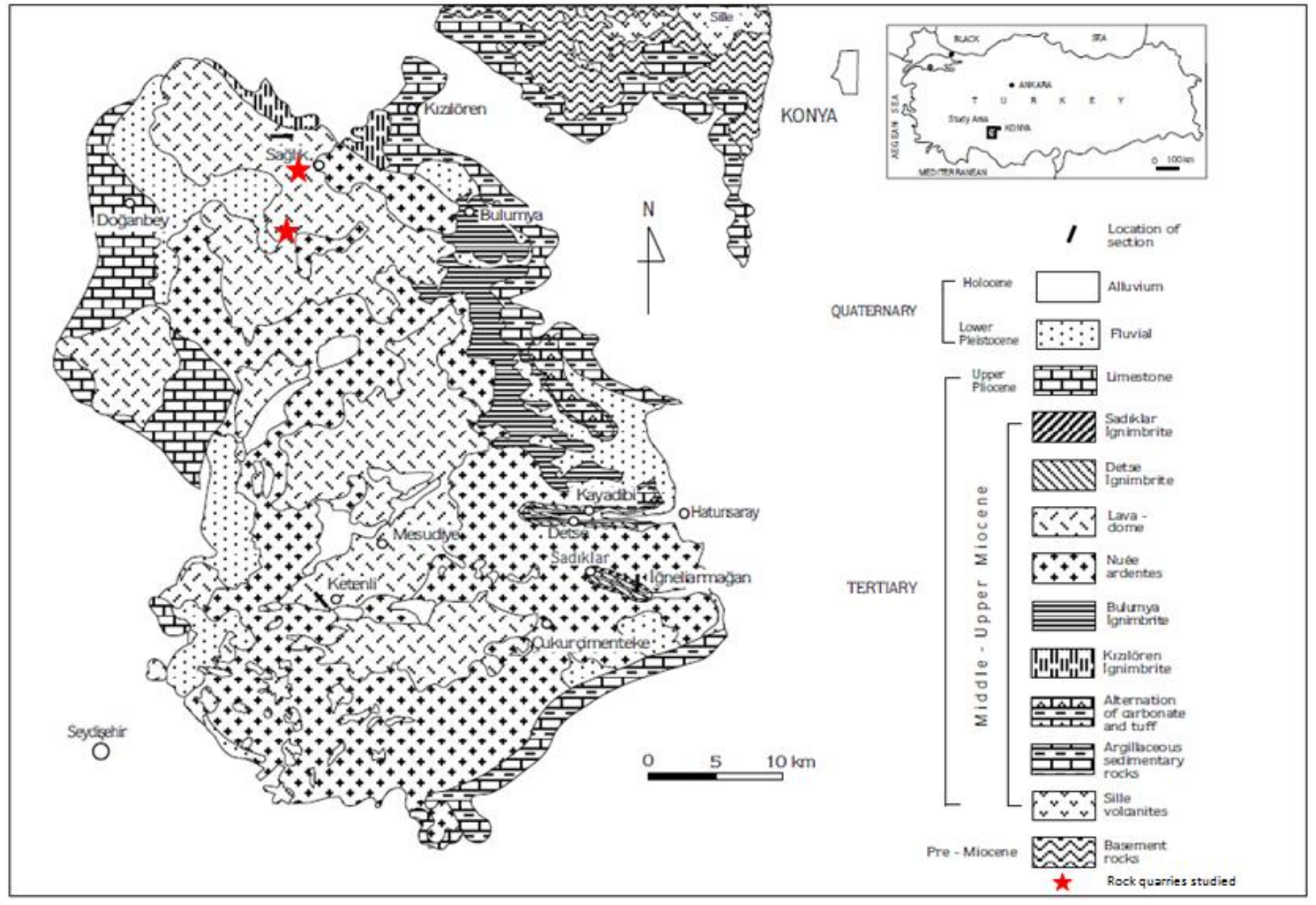

Figure 1: The location and the geologic map of the study area (Modified from [2]).

Within the lava domes, there are a few rock quarries at Yatagan and Saglik area (Figure 2), in where mafic-and felsic magma interactions can be clearly observed. Mafic micrograined enclaves (MME) in the lava range in size from a few $\mathrm{cm}$ to a few meters, and shapes from angular to elips/rounded, with well-developed chilly zone. The samples were collected at the 
quarries, opened within the lavas, to determine to the geochemical characteristics of the lava domes.

\section{SAMPLING AND ANALYTICAL METHODS}

About 50 thin-sections from the lava domes were examined petrographically. Of these, selected samples were analysed for minerals and whole-rock major, trace and REE. Whole rock analyses for major and trace elements were carried out with Inductively-Coupled Plasma Emission Spectrometer from pulps after $0.2 \mathrm{~g}$ rock-powder were fused with $1.5 \mathrm{~g} \mathrm{LiBO}_{2}$ and then dissolved in $100 \mathrm{~mm} 3$ 5\% HNO3 at ACME Analytical Laboratories Ltd., Vancouver, Canada. The REE contents were determined by Inductively-Coupled Plasma Mass Spectrometry from pulps after $0.25 \mathrm{~g}$ rock-powder was dissolved with 4 acid digestions at ACME (Canada). Analytical uncertainties vary from $0.1 \%$ to $0.04 \%$ for major elements; from 0.1 to $0.5 \%$ for trace elements; and from 0.01 to $0.5 \mathrm{ppm}$ for rare earth elements.

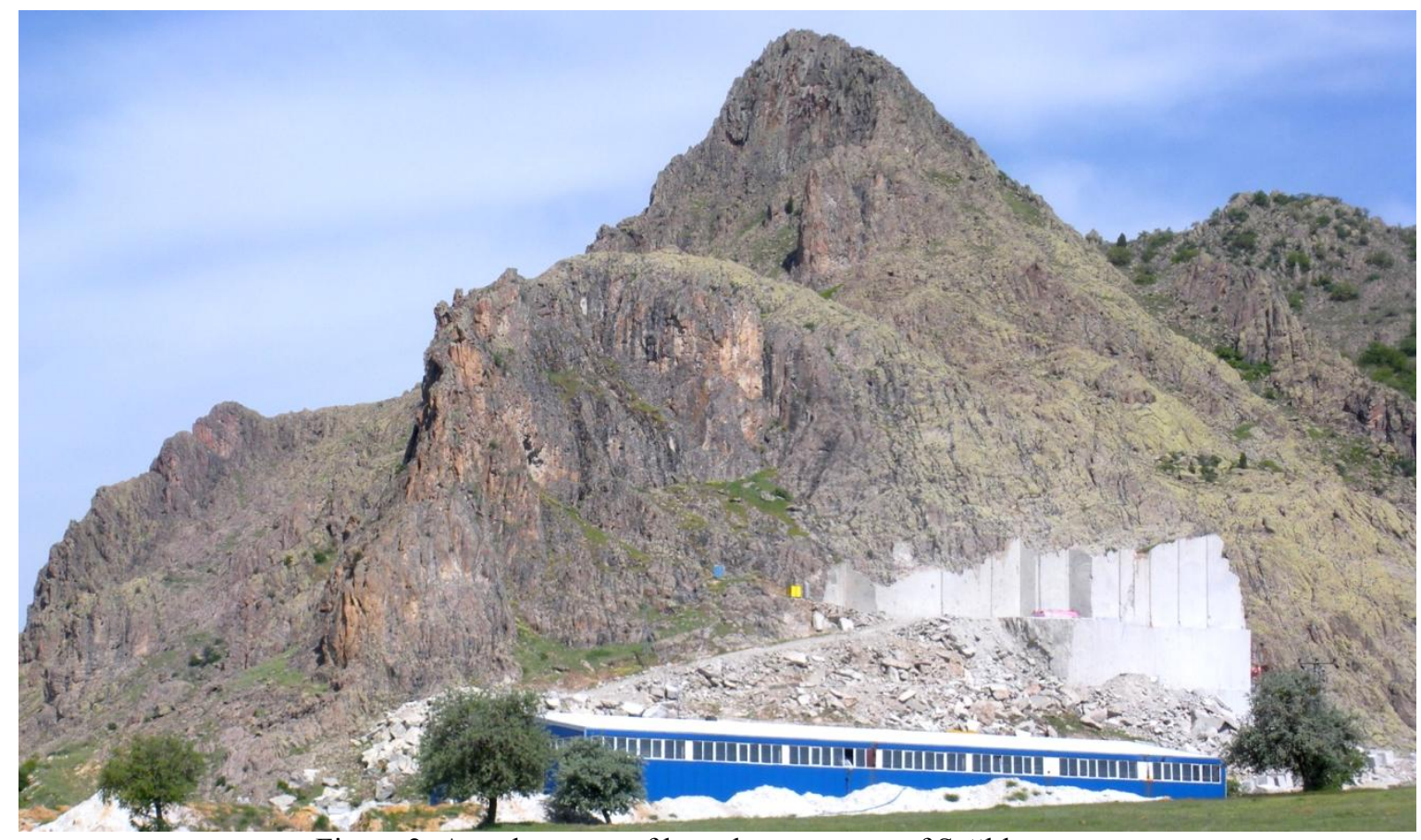

Figure 2: A rock quarry of lava dome at west of Sağlık area.

\section{PETROGRAPHY}

It is made up predominantly of plagioclase (15-45\%), amphibole (3-15\%), opaque iron ore (3-20\%), rare biotite (5-10\%), quartz (0-5), sanidine (0-5\%), clinopyroxene (0-5\%), epidote $(0-8 \%)$ and accessory apatite and zircon in holocrystalline-hypocrystalline porphyric texture (Figure 3), and glomeroporphyric texture. Matrix in the samples contain mostly plagioclase, pyroxene, opaque iron ore and volcanic glasses.

The plagioclase crystals $(0.6-3.2 \mathrm{~mm})$ are mostly subhedral and show albite-carlsbad twinning, oscillatory zoning and sieve texture. Sericitisation and sousuritisation are common alteration types in the plagioclase. The amphiboles $(0.4-3.0 \mathrm{~mm})$ show strong pleochroism in the shades of yellowish brown to reddish brown colour, with plagioclase inclusions. It is altered to an aggregate of opaque mineral, chlorite and epidote $(0.6 \mathrm{~mm})$. The biotite forms as subhedral laths shows strong pleochroism, from light to dark brown. It is replaced to amphiboles, and mostly surrounded by a reaction rim composed of plagioclase, epidote and quartz. The quartz 
phenocrysts $(0.4-2.0 \mathrm{~mm})$ is subhedral and sometimes resorbed. The pyroxene occurs only in a few samples, and typically has no color.

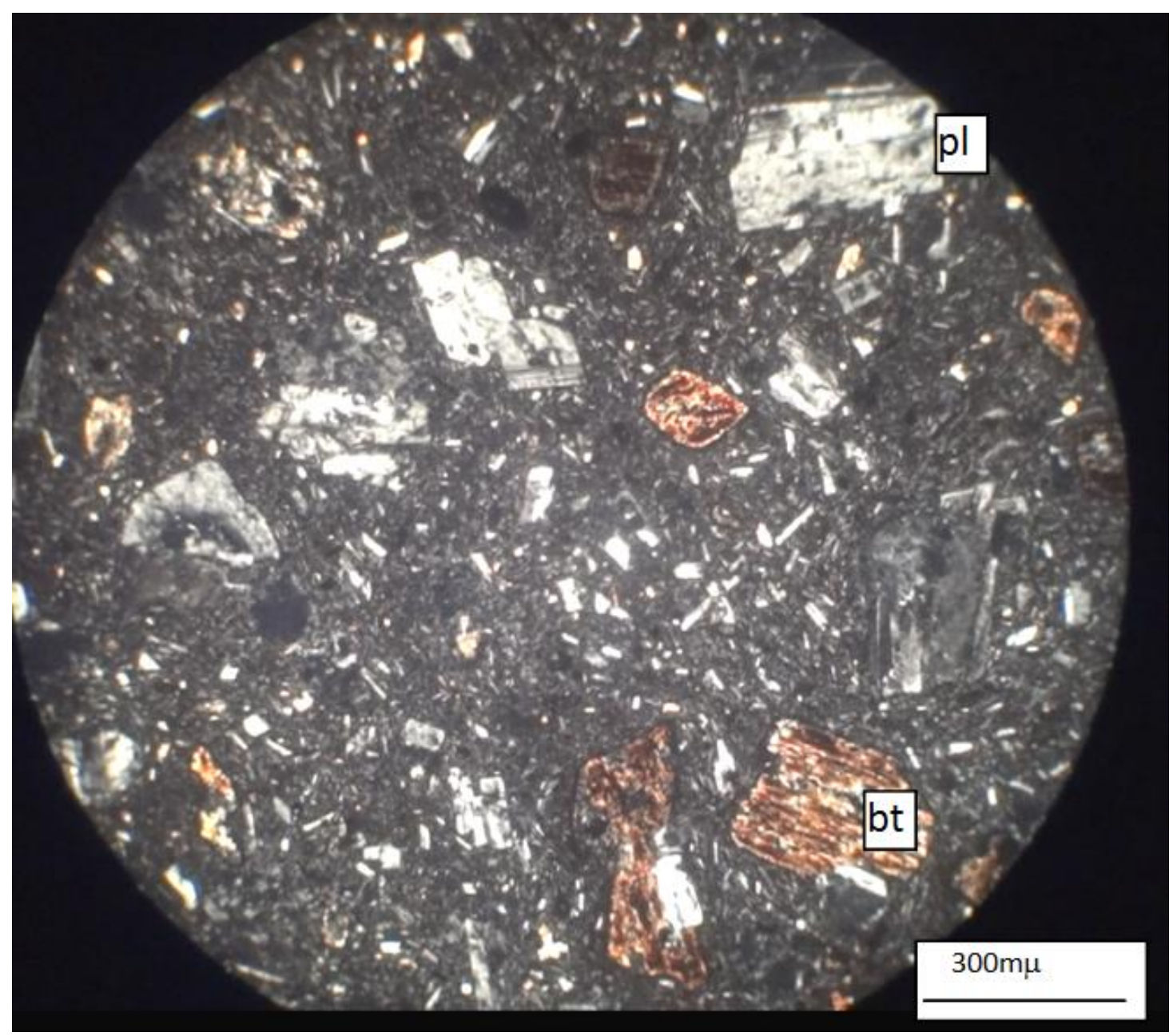

Figure 3: A microphotograph of the sample with porphric texture. 40A-1b (Cross Nicols). Bt: biotite, pl: plagioclase

\section{GEOCHEMISTRY}

Major and trace elements

Results of the bulk rock chemical analyses are given in Table 1. The samples are calcalkaline, high-K calcalkaline and metaluminous in composition (Figure 4a, b, d). However, Erenlerdagi volcanics as a whole range in composition from calc-alkaline through High $\mathrm{K}$ calc-alkaline to shoshonite (Figure 4c). In Figure 5a, the samples are plotted clearly in both andesite and dacite areas while the samples are found on basalt/basaltic andesite and dacite/rhyolite areas in trace element nomenclature diagram (Figure 5b). In Harker variation diagrams (Figure 6), $\mathrm{SiO}_{2}$ increases with decreasing $\mathrm{TiO}_{2}, \mathrm{Al}_{2} \mathrm{O}_{3}, \mathrm{FeOt}, \mathrm{MgO}$ and $\mathrm{CaO}$, suggesting fractional crystallization of amphibole ( \pm olivine, \pm pyroxene), ilmenite/titanomagnetite. $\mathrm{SiO}_{2}$ also shows negative correlation with $\mathrm{Eu} / \mathrm{Eu}^{*}, \mathrm{Sr}$ (Figure 7), suggesting plagioclase fractionation. Existence of negative correlation between $\mathrm{SiO}_{2}$ and $\mathrm{V}$ also confirm titanomagnetite fractionation in the samples. $\mathrm{SiO}_{2}$ shows however, a negative correlation with both $\mathrm{K}$ and $\mathrm{Rb}$, possibly due to biotite being remained in the melt. 
Table 1: Major, trace and rare earth element analyses of the samples.

\begin{tabular}{|c|c|c|c|c|c|c|c|c|c|c|c|c|c|c|c|c|}
\hline Sample & 1B & $2 C$ & $3 B$ & $4 \mathrm{~B}$ & $5 \mathrm{~B}$ & $7 \mathrm{~B}$ & $8 \mathrm{~B}$ & $9 \mathrm{C}$ & 11B & $40 \mathrm{~B}$ & 41B & $42 B$ & $43 B$ & $44 B$ & $46 \mathrm{~B}$ & 47B \\
\hline $\begin{array}{l}\mathrm{SiO} 2 \\
\end{array}$ & 66.11 & 59.9 & 67 & 64.57 & 65.75 & 65.44 & 65.39 & 59.76 & 66.46 & 60.18 & 60.35 & 60.69 & 60.38 & 60.67 & 60.15 & 59.89 \\
\hline TiO2 & 0.45 & 0.8 & 0.45 & 0.47 & 0.47 & 0.47 & 0.48 & 0.83 & 0.43 & 0.8 & 0.79 & 0.79 & 0.78 & 0.79 & 0.8 & 0.83 \\
\hline $\mathrm{Al} 2 \mathrm{O} 3$ & 15.52 & 15.91 & 15.23 & 15.43 & 15.39 & 15.15 & 15.24 & 16.07 & 15.54 & 16.94 & 17.07 & 16.64 & 16.53 & 16.8 & 16.94 & 16.97 \\
\hline $\mathrm{Fe} 2 \mathrm{O} 3$ & 3.76 & 6.3 & 3.68 & 3.74 & 3.78 & 3.84 & 3.95 & 6.27 & 3.57 & 6.11 & 5.99 & 5.95 & 6.12 & 6.04 & 6.01 & 6.19 \\
\hline $\mathrm{MgO}$ & 1.61 & 3.37 & 1.58 & 1.54 & 1.7 & 1.56 & 1.73 & 3.33 & 1.42 & 2.54 & 2.45 & 2.39 & 2.51 & 2.38 & 2.61 & 2.69 \\
\hline $\mathrm{CaO}$ & 3.73 & 5.26 & 3.44 & 4.73 & 4.1 & 4.48 & 4.01 & 5.38 & 3.51 & 5.93 & 5.77 & 5.68 & 5.88 & 5.77 & 5.78 & 6.04 \\
\hline $\mathrm{Na} 2 \mathrm{O}$ & 3.39 & 2.73 & 3.26 & 3.22 & 3.27 & 3.26 & 3.23 & 2.84 & 3.19 & 3.39 & 3.39 & 3.3 & 3.33 & 3.33 & 3.4 & 3.34 \\
\hline $\mathrm{K} 2 \mathrm{O}$ & 3.37 & 2.64 & 3.57 & 3.34 & 3.58 & 3.49 & 3.62 & 2.56 & 3.58 & 2.99 & 2.97 & 3.04 & 2.94 & 3 & 3.01 & 2.96 \\
\hline P2O5 & 0.17 & 0.13 & 0.16 & 0.17 & 0.18 & 0.18 & 0.18 & 0.16 & 0.16 & 0.25 & 0.24 & 0.24 & 0.25 & 0.26 & 0.25 & 0.25 \\
\hline $\mathrm{MnO}$ & 0.08 & 0.13 & 0.07 & 0.1 & 0.08 & 0.1 & 0.1 & 0.12 & 0.07 & 0.11 & 0.11 & 0.1 & 0.11 & 0.11 & 0.11 & 0.11 \\
\hline LOI & 1.6 & 2.6 & 1.3 & 2.4 & 1.4 & 1.8 & 1.8 & 2.4 & 1.8 & 0.4 & 0.5 & 0.9 & 0.8 & 0.5 & 0.6 & 0.4 \\
\hline Sum & 99.75 & 99.79 & 99.75 & 99.75 & 99.75 & 99.75 & 99.75 & 99.74 & 99.75 & 99.64 & 99.65 & 99.67 & 99.66 & 99.66 & 99.65 & 99.65 \\
\hline $\mathrm{Ni}$ & 3.4 & 2.1 & 3.2 & 3 & 3.4 & 3.2 & 3.5 & 2.6 & 3.2 & 2 & 1.9 & 2.4 & 2.6 & 2.3 & 1.8 & 1.9 \\
\hline Co & 6.7 & 12.2 & 7.7 & 8.7 & 8.4 & 7.3 & 7.7 & 14.3 & 8 & 14.6 & 13.7 & 12.8 & 14 & 14.7 & 13.8 & 14.1 \\
\hline $\mathrm{Ga}$ & 17.7 & 17.4 & 16.8 & 16.3 & 16.4 & 15.7 & 16.2 & 17.4 & 16.3 & 18 & 19.3 & 17.5 & 18.7 & 18.3 & 19.2 & 19.1 \\
\hline $\mathrm{Hf}$ & 4 & 4 & 4.1 & 3.5 & 4.7 & 4.1 & 4.8 & 4.3 & 4.2 & 3.9 & 5 & 4.5 & 4.4 & 5.2 & 5.2 & 4.1 \\
\hline $\mathrm{Nb}$ & 13.9 & 12.8 & 14.6 & 14.1 & 15 & 14.1 & 13.4 & 12.2 & 13.3 & 12.5 & 13.5 & 13.1 & 12.1 & 12.6 & 13.8 & 11.4 \\
\hline $\mathrm{Rb}$ & 125.9 & 93.4 & 130.5 & 115.2 & 131.6 & 122.7 & 130.4 & 99.6 & 135.3 & 92.3 & 91.9 & 95.5 & 94.4 & 96.9 & 93 & 90.3 \\
\hline $\mathrm{Ba}$ & 1024 & 490 & 1027 & 984 & 1015 & 980 & 988 & 621 & 981 & 1151 & 1103 & 1055 & 1120 & 1176 & 1134 & 1087 \\
\hline $\mathrm{Sr}$ & 529.2 & 524.9 & 501.8 & 514.5 & 503.7 & 541 & 479.4 & 577.4 & 518.8 & 949.5 & 906.7 & 858.2 & 906.4 & 878.4 & 900.7 & 925.6 \\
\hline $\mathrm{Pb}$ & 3.2 & 5.4 & 3.5 & 2.4 & 2.8 & 3.5 & 2.5 & 5 & 7.8 & 2.3 & 1.9 & 1.8 & 1.8 & 1.9 & 2 & 2.1 \\
\hline $\mathrm{Zn}$ & 27 & 35 & 23 & 30 & 31 & 25 & 26 & 39 & 35 & 19 & 15 & 17 & 20 & 18 & 16 & 14 \\
\hline $\mathrm{Ta}$ & 1.3 & 1 & 1.5 & 1.1 & 1.4 & 1.2 & 1.3 & 1 & 1.2 & 1 & 0.7 & 1.2 & 1 & 1 & 0.9 & 0.9 \\
\hline Th & 23.3 & 20.4 & 26.8 & 23.7 & 26.7 & 24.4 & 24.6 & 17.7 & 25.7 & 21.2 & 21.3 & 20.7 & 22 & 22.3 & 21.3 & 20.7 \\
\hline $\bar{U}$ & 7.7 & 6.3 & 8.8 & 7.7 & 9 & 8.9 & 9 & 7.3 & 8.1 & 6.6 & 6.3 & 6.3 & 6.2 & 6.5 & 6.5 & 6.4 \\
\hline $\mathrm{Zr}$ & 151.2 & 133.7 & 166.7 & 143.6 & 168.6 & 155.5 & 170.3 & 146.1 & 157.6 & 173.2 & 168.1 & 164.1 & 174.5 & 175.2 & 170.2 & 164.5 \\
\hline Y & 17.5 & 21.2 & 18.5 & 18.6 & 19.1 & 18.2 & 18.6 & 23.2 & 17.8 & 23.9 & 24.9 & 21.6 & 22.1 & 25.1 & 21.9 & 22.8 \\
\hline $\mathrm{La}$ & 42.5 & 31.6 & 46.9 & 42.8 & 46.6 & 44.1 & 41.4 & 32 & 42.1 & 49.1 & 51.4 & 46 & 49 & 53 & 51.4 & 49.8 \\
\hline $\mathrm{Ce}$ & 71.5 & 56.7 & 80.9 & 75.2 & 82 & 76.9 & 72 & 58.8 & 73 & 86.4 & 84.6 & 83.1 & 84.4 & 86.7 & 88.4 & 85 \\
\hline $\mathrm{Pr}$ & 7.3 & 6.32 & 8.32 & 7.83 & 8.47 & 7.96 & 7.56 & 6.49 & 7.38 & 9.6 & 9.35 & 9 & 9.26 & 9.75 & 9.51 & 9.41 \\
\hline $\mathrm{Nd}$ & 28.6 & 23.7 & 26.8 & 26.9 & 29.8 & 26.8 & 25.8 & 23.9 & 27.3 & 37.1 & 33.8 & 34.6 & 34.1 & 35.5 & 35.5 & 36.3 \\
\hline $\mathrm{Sm}$ & 4.41 & 4.25 & 4.48 & 4.41 & 4.79 & 4.09 & 4.7 & 4.48 & 4.2 & 5.94 & 5.54 & 5.71 & 5.78 & 6.16 & 5.82 & 5.69 \\
\hline Eu & 1.04 & 1.1 & 0.97 & 0.97 & 1.03 & 0.96 & 0.97 & 1.02 & 0.95 & 1.42 & 1.37 & 1.38 & 1.42 & 1.49 & 1.45 & 1.4 \\
\hline Gd & 3.88 & 4.07 & 4.22 & 4.14 & 4.49 & 3.86 & 4.09 & 4.32 & 3.64 & 5 & 5.07 & 4.95 & 5.3 & 5.22 & 5.08 & 5.08 \\
\hline $\mathrm{Tb}$ & 0.54 & 0.64 & 0.59 & 0.56 & 0.6 & 0.57 & 0.58 & 0.68 & 0.53 & 0.7 & 0.7 & 0.67 & 0.72 & 0.77 & 0.7 & 0.73 \\
\hline Dy & 3.3 & 3.71 & 3.76 & 3.46 & 3.21 & 3.43 & 3.47 & 4.18 & 3.3 & 3.84 & 3.93 & 4.15 & 3.58 & 4.68 & 3.62 & 3.79 \\
\hline $\mathrm{Ho}$ & 0.6 & 0.88 & 0.58 & 0.56 & 0.65 & 0.64 & 0.68 & 0.84 & 0.56 & 0.8 & 0.86 & 0.69 & 0.79 & 0.98 & 0.81 & 0.77 \\
\hline $\mathrm{Er}$ & 1.96 & 2.32 & 2.03 & 1.92 & 1.91 & 1.74 & 1.92 & 2.63 & 1.91 & 2.23 & 2.74 & 1.98 & 2.29 & 2.36 & 2.49 & 2.42 \\
\hline $\mathrm{Tm}$ & 0.27 & 0.4 & 0.27 & 0.29 & 0.29 & 0.34 & 0.3 & 0.33 & 0.26 & 0.31 & 0.37 & 0.31 & 0.36 & 0.38 & 0.32 & 0.36 \\
\hline $\mathrm{Yb}$ & 1.6 & 2.2 & 1.99 & 1.69 & 1.87 & 1.88 & 1.77 & 2.12 & 2 & 2.31 & 1.91 & 2.23 & 2.21 & 2.59 & 2.23 & 2.3 \\
\hline Lu & 0.29 & 0.41 & 0.33 & 0.31 & 0.33 & 0.29 & 0.28 & 0.39 & 0.25 & 0.32 & 0.33 & 0.32 & 0.3 & 0.35 & 0.33 & 0.39 \\
\hline
\end{tabular}




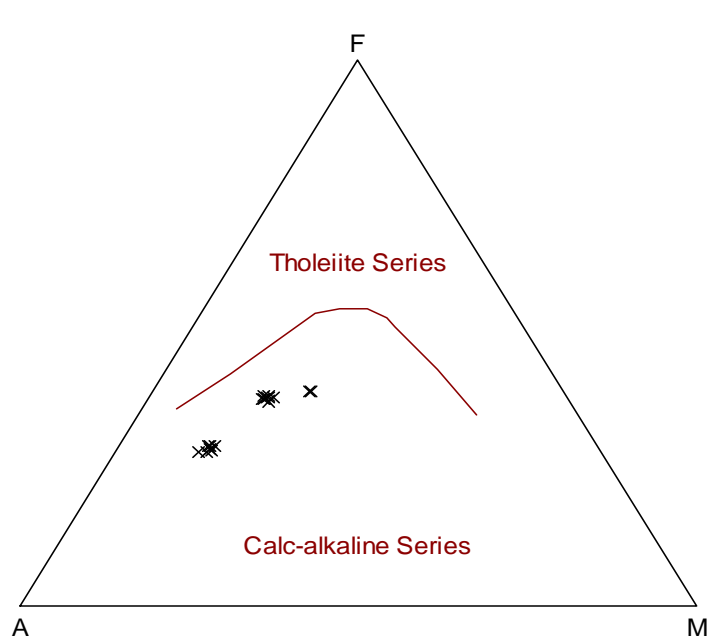

Figure 4a: An AFM diagram [11].

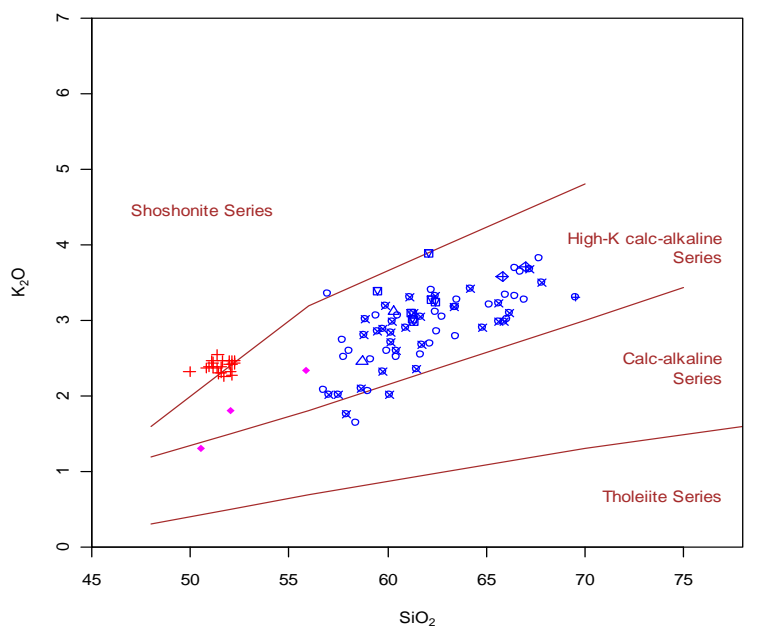

Figure 4c: $\mathrm{K}_{2} \mathrm{O}$ vs $\mathrm{SiO}_{2}$ diagram of the Erenlerdagi volcanics [12],

Data from [5] (blue symbols), and [13] (red symbols: sill).

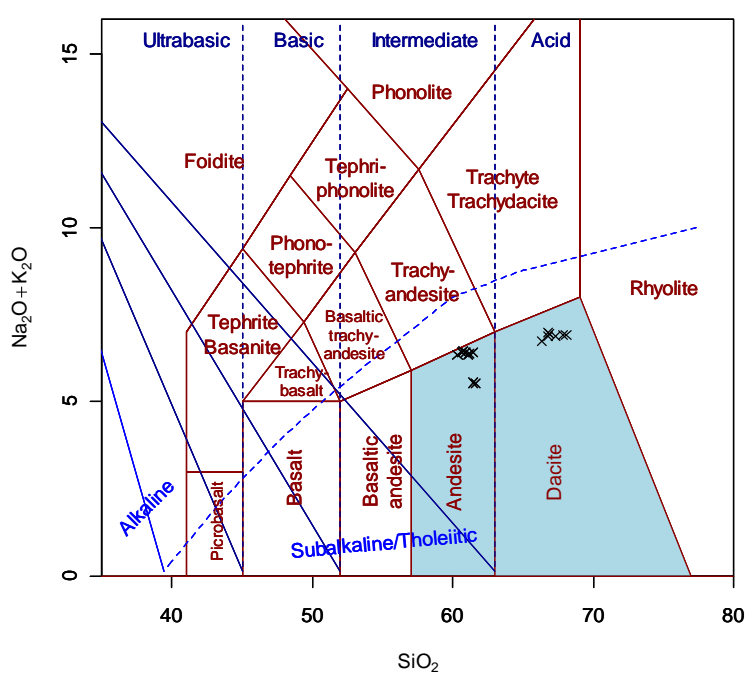

Figure 5a: Nomenclature diagram of the samples. $\mathrm{SiO}_{2}$ vs $\mathrm{Na}_{2} \mathrm{O}+\mathrm{K}_{2} \mathrm{O}$ diagram [15].

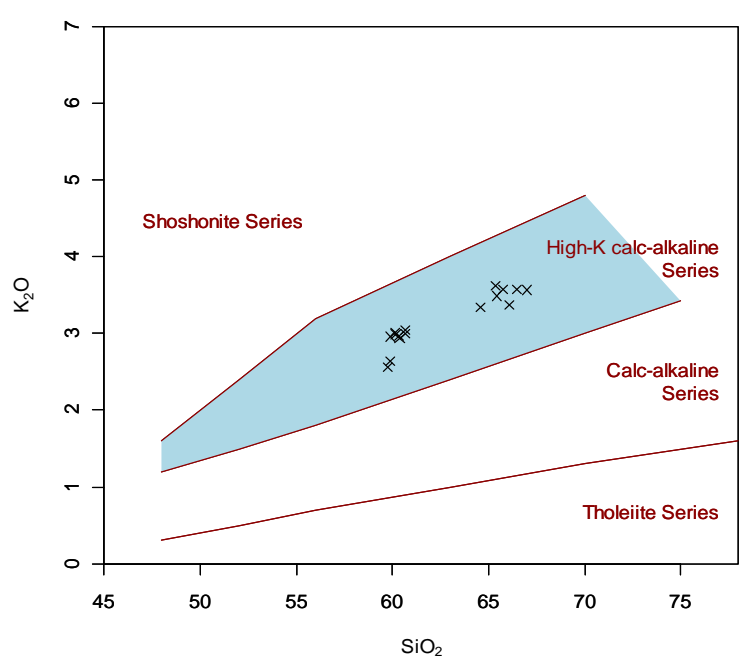

Figure 4b: K2O vs $\mathrm{SiO} 2$ diagram of the samples

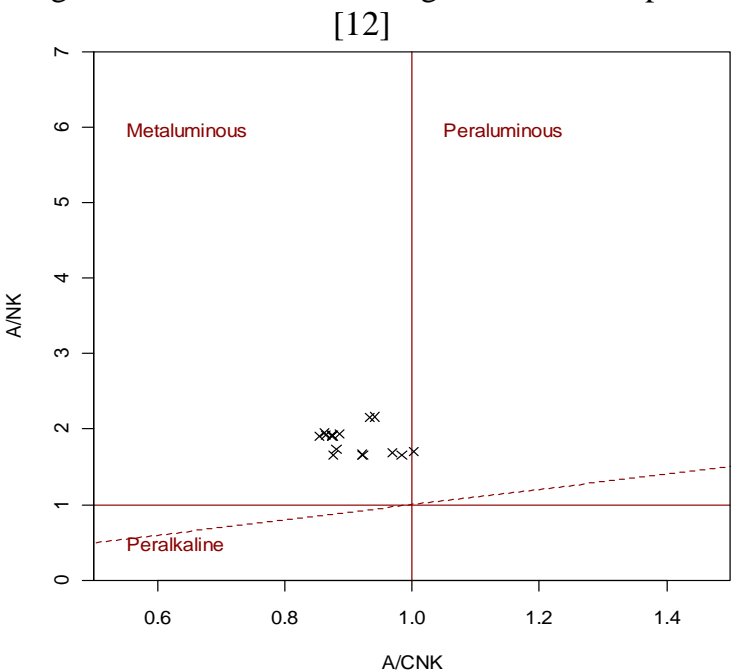

Figure 4d: ACNK-ANK diagram [14].

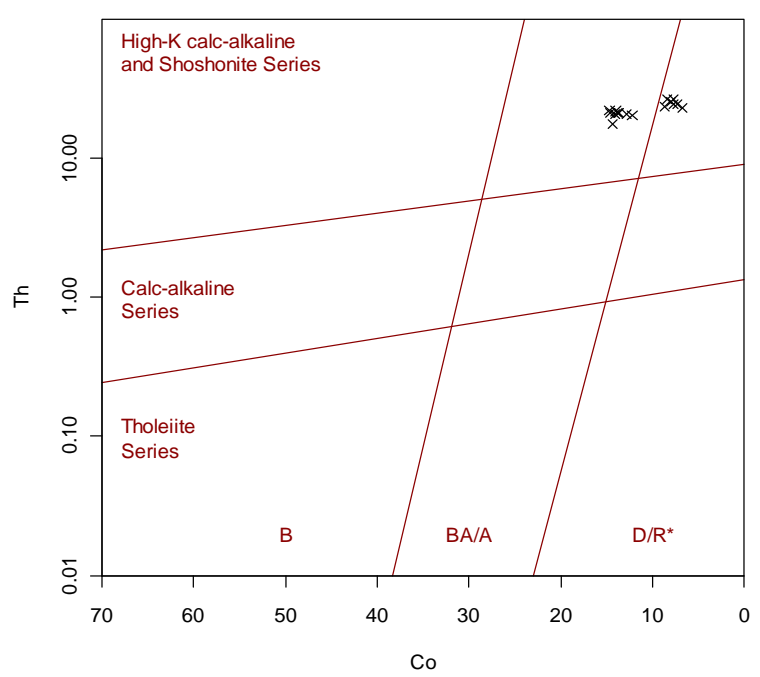

Figure 5b: Nomenclature diagram of the samples. Th vs Co plot [16] 


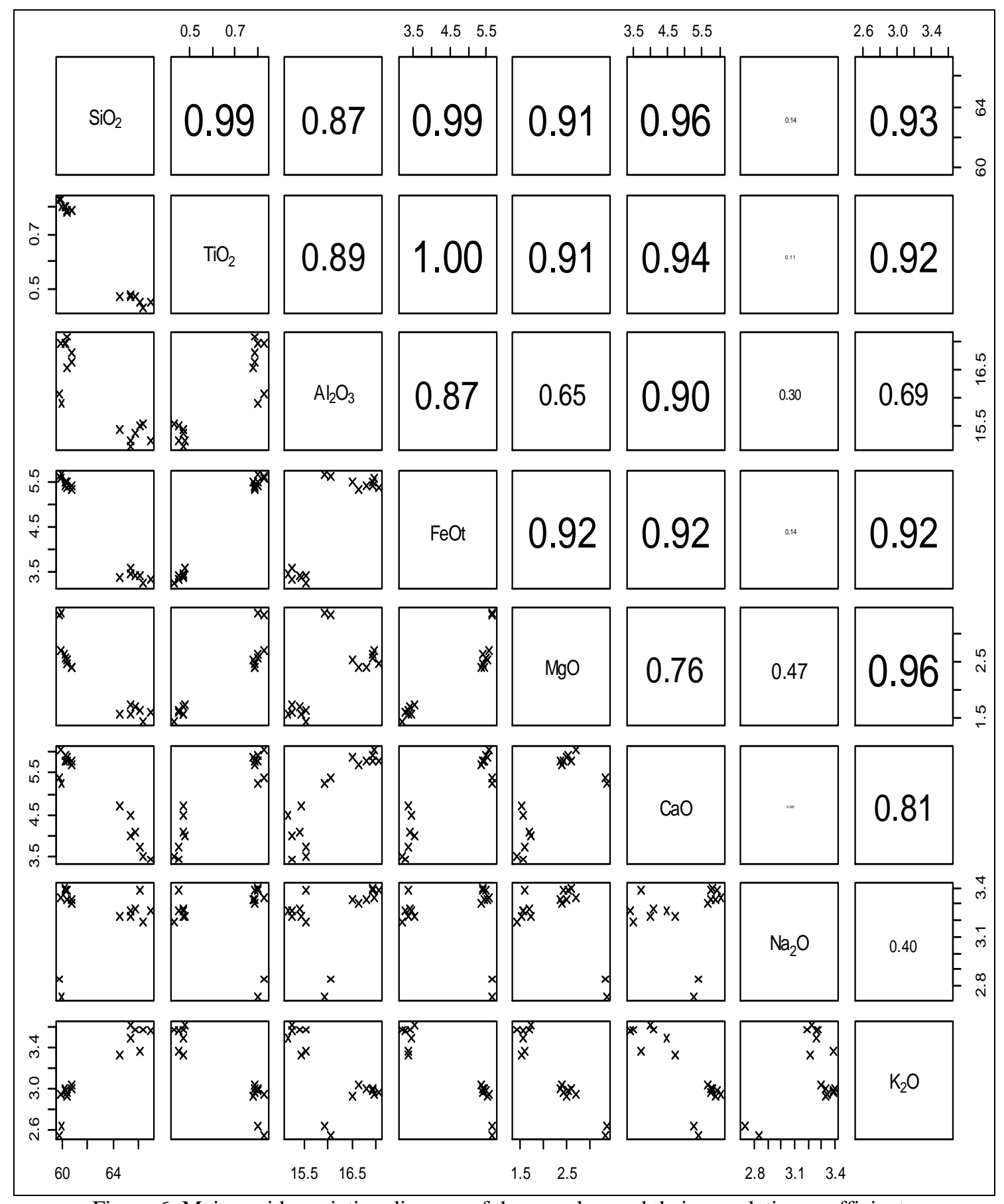

Figure 6: Major oxide variation diagram of the samples, and their correlation coefficients 


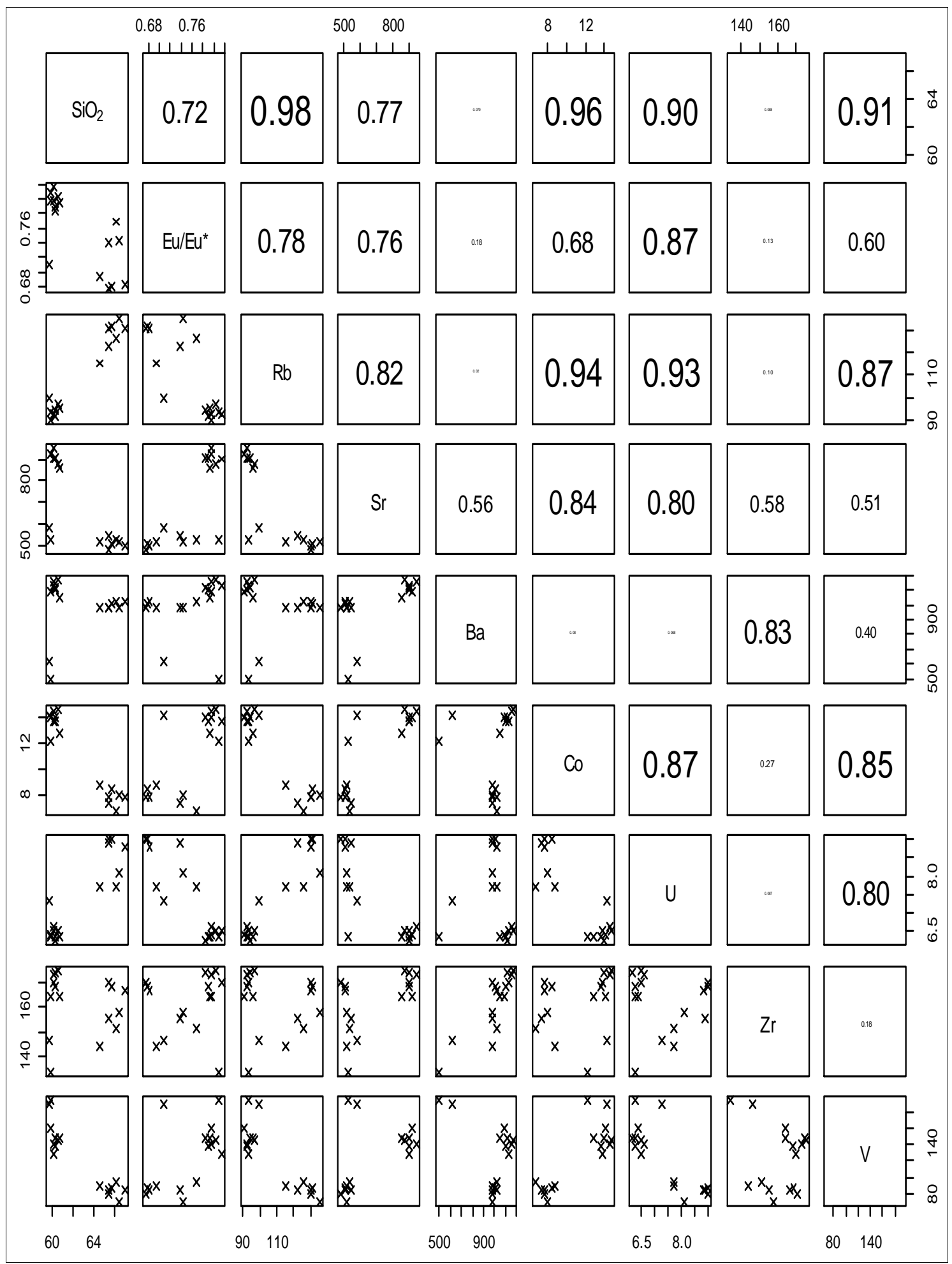

Figure 7: Harker variation diagrams of some trace element, with their correlation coefficients 
Primitive mantle-normalized spider diagrams (Figure 8a) of the samples show an enrichment in Large Ion Lithophile Elements (LILE, e.g. Cs, Ba), and depletion in High Field Strength Element (HFSE, e.g. Y, Yb). The diagrams have negative anomalies of $\mathrm{Rb}, \mathrm{Ba}, \mathrm{Nb}, \mathrm{Pb}$ ve $\mathrm{TiO}_{2}$.

Chondrite-normalized Rare earth Element (REE) pattern of the samples show a Light Rare Earth Elements (LREE) enrichment, and Heavy Rare earth Element (HREE) depletion (Figure $8 b)$, resulted with high $(\mathrm{La} / \mathrm{Lu})_{\mathrm{N}}$ ratios $\left((\mathrm{La} / \mathrm{Lu})_{\mathrm{N}} 8.2-18.0\right)$. Existence of negative Eu anomaly (Eu/Eu*: 0.66-0.80 ) also confirm plagioclase fractionation, or plagioclase-rich parent rocks

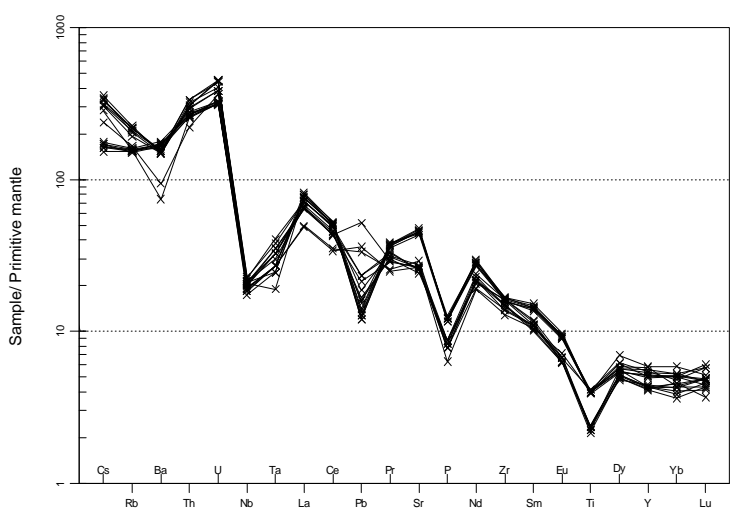

Figure 8a: Primitive mantle-normalized spider diagrams of the samples. Normalizing values are from [17]

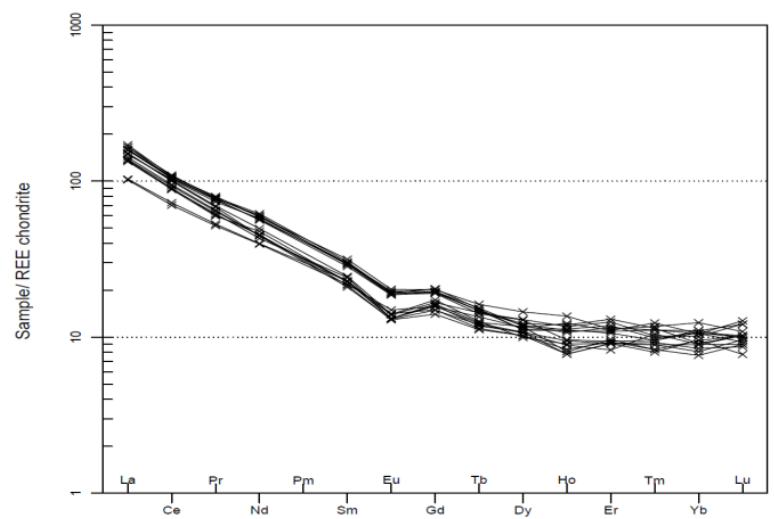

Figure 8b: Chondrite normalized rare earth element patterns of the samples. Normalizing values are from [18]

\section{GEOTECTONIC SETTING}

The samples have low-intermediate $\mathrm{Nb}$ (11-15ppm), $\mathrm{Zr}$ (134-175 ppm), Y (17-25 ppm), and $\mathrm{TiO}_{2}(0.43-0.0 .83 \mathrm{wt} \%)$ contents, which is typical for calc-alkaline associations. Low $\mathrm{La} / \mathrm{Th}$ (1.5-2.4) and intermediate-high $\mathrm{Ba} / \mathrm{Nb}(38-95)$ ratios in the samples are also caracteristics for subduction-related magma [19]. High $\mathrm{Ba} / \mathrm{Th}$ ratio in the samples, mostly $>450$, also show similarity to the orogenic magmatism [20]

Geotectonic diagrams for granites are used to constrain the tectonic setting of the samples, as their composition ranges from rhyolite, through dacite to andesite. In diagrams of [21], the samples are situated mostly on Active Continental Margin areas (Figure 9a, b). All samples are plotted on the fields of Volcanic Arc Granitoids and Post orogenic granite in Figure 9c,d. In a $\mathrm{Hf}-3 \mathrm{Ta}-\mathrm{Rb} / 30$ ternary diagram, the samples are found both on the areas of Volcanic Arc Granitoids and Late-post colision granite (Figure 9e). 


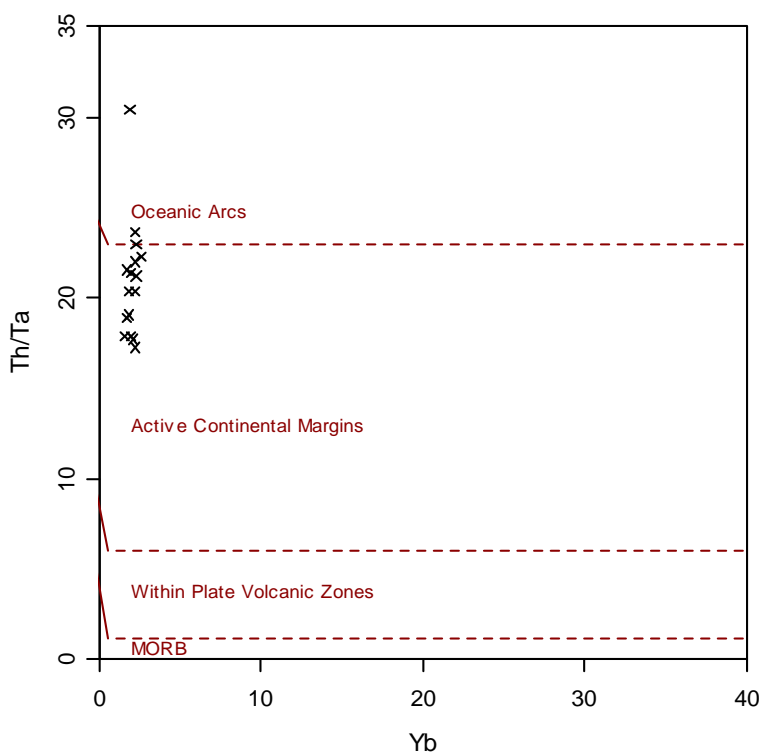

Figure 9a:

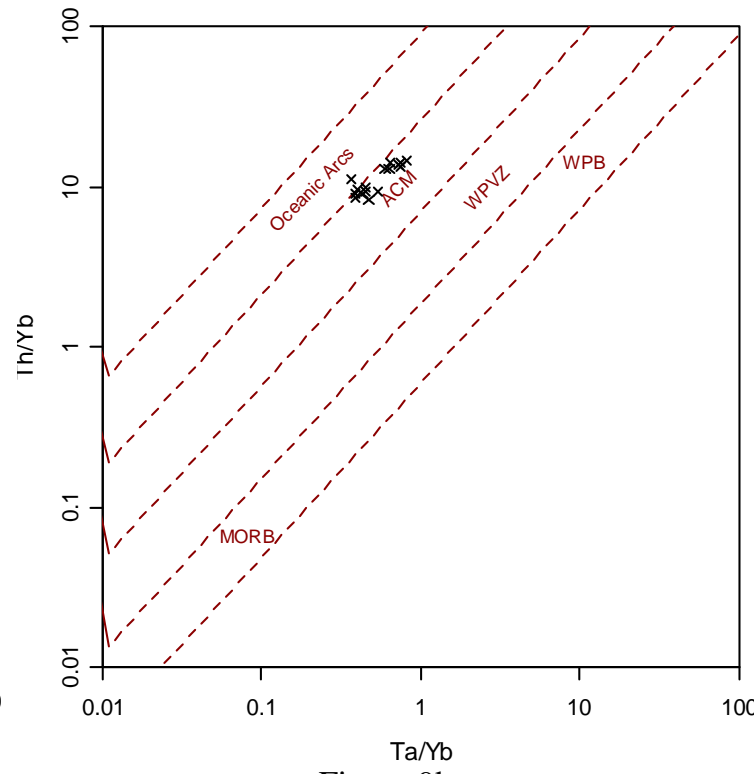

Figure 9b:

Figure 9a\&b:Geotectonic setting of the samples; Yb vs. Th/Ta and Ta vs. Th respectively [21]

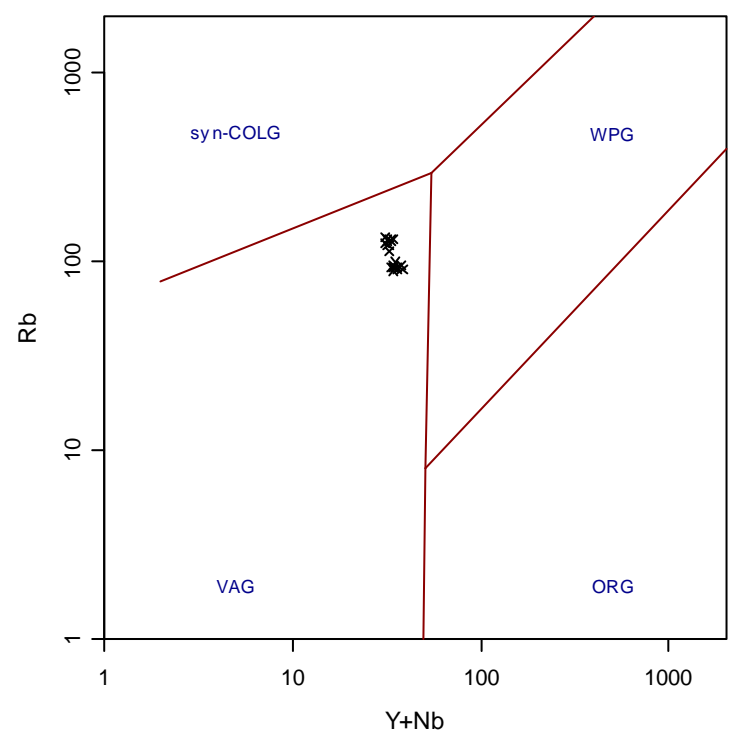

Figure 9c:

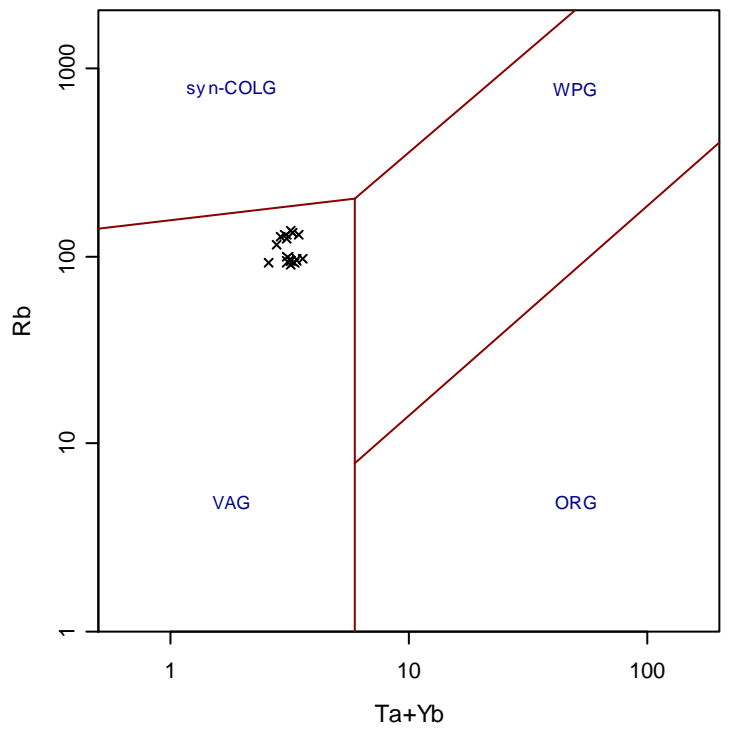

Figure 9d:

Figure 1c\&d:Geotectonic setting of the samples; $\mathrm{Y}+\mathrm{Nb}$ vs. $\mathrm{Rb}$ and $\mathrm{Ta}+\mathrm{Yb}$ vs $\mathrm{Rb}$ respectively [22], [23]; 


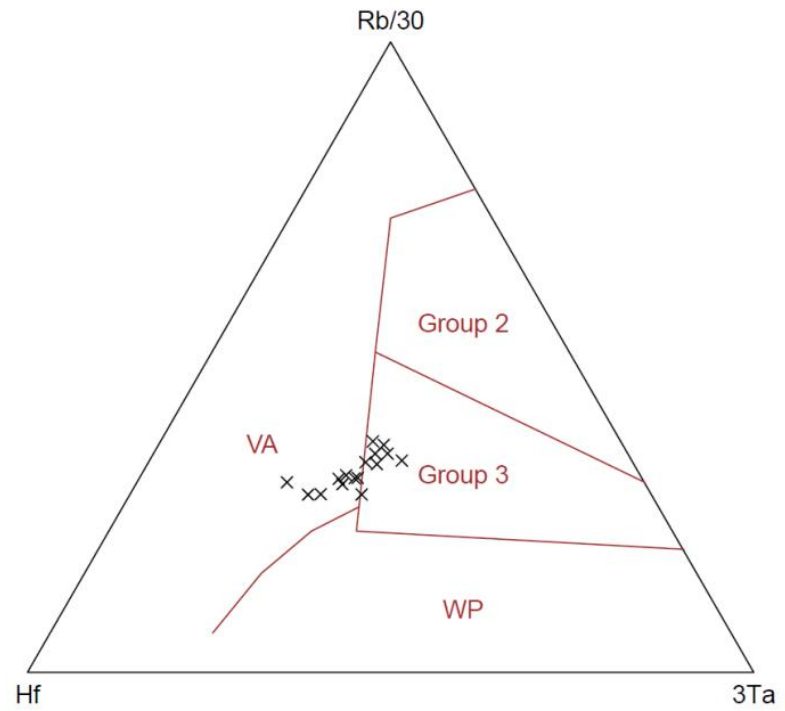

Figure 9e: Geotectonic setting of the samples; Hf-3Ta-Rb/30 ternary diagram [24];

MORB, mid-ocean ridge basalts; WPG, Within-plate granites; Post-orogenic granite Group 3: Late-post colision granite
ACM, Active Continental Margin Post-orogenic granite VA: Volcanic arc granite
Syn-COLLG, syn-collisional granite; ORG, Ocean-ridge granite; POG, Group 2: syn-collisional granite

\section{DISCUSSION \& CONCLUSIONS}

Geochemical data suggests that the crystal fractionation played a significant role in the genesis of the volcanic rocks during ascending of a homogeneous magma. Existence of various MMEs in the volcanics also suggests that magma mixing/mingling processes affected on the chemical composition of the samples. All samples are metaluminous in composition, with ASI values < 1.1, suggesting an igneous source. Therefore, the lava samples could have been formed by partial melting of an igneous source (basic rocks) coupled with contamination and fractional crystallization of amphibole ( \pm olivine, \pm pyroxene), ilmenite/titanomagnetite in relation with the subduction of the African plate underneath the Anatolian plate during Miocene. Tatar et al.(2002) also suggest that the oldest Sille volcanics (11.7-11.4 Ma) rotated anticlockwise during early stages of crustal thickening and deformation before later Miocene episode (c. 10.9-8.9 Ma, $\left.D=183^{\circ}, I=-47^{0}\right)$ and a Mio-Pliocene episode $\left(D=179^{0}, I=-51^{0}\right)$.

The samples were usually enriched in LILE, and depleted in HFSE, similar to the arc magmatics [25], [26]. Calc-calkaline character of the samples are also in accordance with this suggestion. However, existence of trachyandesite composition of the samples, with late- postcolliginal tectonic setting on the geotectonic setting may suggest that the samples might have been affected by extensional tectonics after contraction regime. The samples may thus represent late/postcolligional volcanism in the area. 


\section{REFERENCES}

[1] Ketin, O. Türkiye jeolojisine genel bir bakis,. İTÜ Matbaasi, 596 pp, 1983.

[2] Keller, J., Jung, D., Burgath, K., Wolf, F. Geologie und petrologie des Neogenen kalkalkalivulkanismus von Konya_Erenler Dag־-Alaca Dag־-Massiv Zentral-Anatolian.. Geo. Jb. B 25, pp 37-117, 1977.

[3] Ota, R. and Dincel, A. Volcanic rocks of Turkey, Bulletin of the Geological Survey of Japan 26, pp 393-419, 1975.

[4] Ulu, Ü., Bulduk, A.K., Ekmekçi, E., Karakaş, M., Öcal „H., Arbas , A., Saçlı , L., Taşkıran , M.A., Adır , M., Sözeri , Ş. \& Karabıyıkoğlu , M. İIlice - Akkise ve CihanbeyliKarapinar Alanının Jeolojisi . Mineral Research Exploration Institute of Turkey Report No: 9720, 1994 [in Turkish, unpublished]

[5] Temel, A., Gündoğdu, M.N., Gourgaud, A. Petrological and geochemical characteristics of Cenozoic high-K calc-alkaline volcanism in Konya, Central Anatolia, Turkey. J. Volcanol. Geotherm. Res. 85, 327-354, 1998.

[6] Tatar, O. Gürsoy, H. \& Piper, J. D. A. Differential neotectonic rotations in Anatolia and the Tauride Arc: palaeomagnetic investigation of the Erenlerdagi Volcanic Complex and Isparta volcanic district, south-central Turkey, Journal of the Geological Society, London, Vol. 159, pp. 281-294, 2002.

[7] Karakaş, Z. and Kadir, S. Devitrification of volcanic glasses in Konya volcanic units. Turkish Journal of Earth Sciences. V.9, N.1, 39-46. Istanbul, 595 s, 2000.

[8] Kurt, H., Özkan, A.M. and Koçak, K. Geology, Petrography And Geochemistry Of The Subduction Related Volcanic Rocks, West Of Konya, Central Anatolia, Türkiye Jeoloji Bült, 46/2, 39 - 51, 2003.

[9] Kurt. A, Akgül, B., Kurt, H. Sağlık - Erenkaya (Konya Batısı) Yöresi volkanik Kayaçlarının Petrografik ve Jeokimyasal Özellikleri, F. Ü. Fen ve Mühendislik Bilimleri Dergisi, 17 (1), 190-204, 2005 [in Turkish, with English abstract].

[10] Bering, D. Lithostratigraphie, tektonische Entwicklung und Seengeschichte der Neogenen und Quartaren intramontanen Becken und der Pisidischen Seenregion (Sud-anatolien) Geomogische Jahrbuch 101, p 150, Hannover, 1971.

[11] Irvine, T. N. and Baragar, W. R. A. Guide to the chemical classification of the common igne-ous rocks. Canadian Journal of Earth Sciences 8, pp 523-548, 1971.

[12] Peccerillo, A and Taylor, S.R. Geochemistry of Eocene calcalkaline volcanic rocks from the Kastamonu area, northern Turkey. Contrib Mineral Petrol 58, pp 63-81, 1976.

[13] Kerim KOÇAK, Geochemical characteristics of the Late Miocene to Pliocene Ulumuhsine sill of the Erenlerdagi volcanics, Konya, Central Turkey, Ore potential of alkaline, kimberlite and carbonatite magmatism, 2012, 14-18 September, Sudak, Ukraine.

[14] Shand, S. J. The Eruptive Rocks, 2nd edn. New York: John Wiley, pp $444 \quad, 1943$.

[15] Le Bas, M.J., Le Maitre, R.W., Streckeisen, A., Zanettin, B. A chemical classification of volcanic rocks based on the total alkali-silica diagram. J. Petrol. 27, 745-750, 1986.

[16] Hastie, A.R., Kerr, A.C., Pearce, J.A., Mitchell, S.F. Classification of Altered Volcanic Island Arc Rocks using Immobile Trace Elements: Development of the Th-Co Discrimination Diagram. Journal of Petrology, v. 48, p. 2341-2357, 2007.

[17] Sun, S.S McDonough, W.F. Chemical and isotopic systematics of oceanic basalts: implications for mantle composition and processes, in Saunders AD and Norry MJ (eds) 
Magmatism in the Ocean Basins, Geological Society Special Publication, 42: pp 313-345, 1989.

[18] Boynton, W.V. Cosmochemistry of the rare earth elements: meteorite studies. In: Henderson P (ed) Rare earth elements. Elsevier, pp 63-114, 1984.

[19] Sun, S.S. Lead isotope study of young volcanic rocks from mid- ocean ridges, ocean islands and island arcs, Phil. Trans. R. Soc. London., A297, pp 409- 455, 1980.

[20] Gill, J. B. Orogenic andesites and Plate tectonics. Springer-Verlag, New York, pp 370, 1981.

[21] Schand, E. S. \& Gorton, M. P. Application of high field strength elements to discriminate tectonic settings in VMS environments. Economic Geology 97, 629 - 642, 2002.

[22] Pearce, J. A., Harris, N. W. \& Tindle, A. G. Trace element discrimination diagrams for the tectonic interpretation of granitic rocks. Journal of Petrology, 25, pp 956-983, 1984.

[23] Pearce, J. A. A user's guide to basalt discrimination diagrams. In: Wyman, D. A. (ed.) Trace Element Geochemistry of Volcanic Rocks: Applications for Massive Sulphide Exploration. Geological Association of Canada, Short Course Notes 12, 79-113, 1996.

[24] Harris, N.B.W., Pearce, J.A., and Tindle, A.G. Geochemical characteristics of collision zone magmatism: Geological Society, London, Special Publications, v. 19, pp. 67-81, 1986.

[25] Parada, M.A., Nystrom J.O. Levi B. Multiple sources for the Coastal Batholith of central Chile (31-34 S): geochemical and $\mathrm{Sr}-\mathrm{Nd}$ isotopic evidence and tectonic implications. Lithos , 46: 505-521, 1999.

[26] Shaw A, Downes H, Thirwall MF. The quartz-diorites of Limousin: elemental and isotopic evidence for Devono- Carboniferous subduction in the Hercynian belt of the French Massif Central. Chem Geol 107:1-18, 1993. 